\title{
sciendo
}

\section{The economic impact of migration in the Era of Globalization}

\author{
Diana Valentina LUPOIU \\ The Bucharest University of Economic Studies, Romania \\ diana.lupoiu1994@gmail.com \\ Cristi RACEANU \\ The Bucharest University of Economic Studies, Romania \\ cristiraceanu94@gmail.com
}

\begin{abstract}
The phenomenon of globalization has greatly influenced migration in recent years in the European Union. In this article we aim to analyze the benefits of migration in the economy by emphasizing the impact of remittances on the economic development of a country. Remittances are considered as an external source of important, stable funds that help the economic development of a country. We identify also the macroeconomic determinants of remittances. For the statistical and econometric analysis of these factors, we have chosen to use the Panel Data Regression for the countries of the European Union. To analyze the benefits of remittances, the most appropriate macroeconomic indicator is GDP. So in the first part of the article we will present the impact of globalization and migration on remittances, and in the second part we will highlight the economic growth through the presence of remittances. This article examines the role of migrants as a particular segment of the market and as a resource for development. All aspects to be analyzed will outline an overview of population emigration and factors that influence the development of the economy at a time when globalization is on the rise.
\end{abstract}

Keywords: globalization, remittances, migration, GDP, Panel Data Regression.

\section{Introduction}

The impact of migration on the country of origin is a complex process, involving not only the knowledge of costs but also the benefits of the migration process at individual, local, national and international level, taking into account the context in which it manifests itself. Emigration, as a phenomenon, can generate economic and social effects for the country of origin as well as for the destination. These effects may be positive or negative. Experts in the field have different views on this aspect.

Migration is an important component of the demographic phenomenon and a fundamental feature of the European population that has a direct influence on globalization. A phenomenon that has grown significantly since 1980, the analysis of this process has spread throughout Europe involving demographic, social, political and economic consequences.

Remittances (money transferred to our country by emigrants) are an external source of budget funding. The amounts of money sent to the country by emigrants were a source of income, perhaps the only one for their families. In this way, living standards have improved, as these money are used to build houses and purchase goods for personal use.

Migrants' remittances have begun to be considered as a development mechanism for 
labor-exporting countries. The main feature of remittances is that they are external sources of private funds.

In an era of globalization, where the population is free to migrate from one state to another without restrictions, of course, the population chooses to remain in a state where the standard of living is better. In this case, most emigrants send home money for their families. We chose to study this phenomenon by panel regression, which shows that remittances are influenced by both: globalization and migration, in a positive sense. of course, as with remittances growth, benefits are also available in the country where these remittances are received. Remittances help boost the economy for poor countries (Romania), and this growth is reflected in GDP. For this reason, a panel regression for countries in the European Union was used in the analysis below.

\section{Literature review}

Considered as a forms of "globalization from below", financial and social remittances are often seen as having rather positive outcomes, as they transfer to countries of origin resources, knowledge, ideas and practices considered as "good such as: human rights, gender equality, community empowerment, voluntary work and charity initiatives" (Conway, et al., 2012: 190).

These remittances are, in fact, the savings of emigrants made in the destination countries, which can be sources of investment in the country of origin. These remittances increase the standard of living and have beneficial effects on family relationships. On the other hand, the fact that one of the family members disappears determines the change of roles within it, which leads to the loss of well-being within the family and even its degradation due to the imbalances in the couple. There are happy cases when the children are left with only one parent, but they can also be left under the custody of their grandparents or other relatives, which subsequently affects their behavior. Sometimes, migrants abandon their children, who eventually reach placement centers. Therefore, the most affected (in some cases the situation is traumatic) are the children, because the people who deal with them can not successfully fulfill the role of father and mother. (Roman, M., Ileanu, B, 2010)

Remittances have nuances, not only microeconomic but also macroeconomic, changing demand for certain products, investment, income distribution, education, health, etc. The effects of bank transactions may be negative if they are used for consumption instead of being used for investments. (Chirtoc, Bălăcescu, 2010)

In a survey of eleven economies in transition in Eastern Europe between 1990-1999, Leon-Ledesma and Piracha (2004) concluded that remittances had a positive effect on productivity and investment in the home country. Welfare accumulation and the potential of migrants could positively and sustainably influence the economic and social development of the countries of origin. The objectives and practices relating to migration, personal finances and financial intermediation are related to the development of the spirit of enterprise and the creation of jobs. Temporary migration may be beneficial to the emigrant as it can help improve emigrants lives, as a consequence of the experience gained through work abroad.

Aggrawal, Demirguc-Kunt and Peria (2011) are studying the impact of remittances on fi nancial development, Anghelache, Niţă and Badiu (2016), Giuliano and Ruiz-Arranz (2009) are considering the significant role of remittances in the construction of financial resources and economic development. 


\section{Methodology}

In this paper we use a panel model for the 28 countries of the European Union. In the first part of the model, we will look at whether remittances are dependent on independent variables: the number of emigrants and globalization. And in the second part of the study we will analyze the dependence of GDP on the remittance variable.

The model below is a particular form of the linear regression model adapted for our analysis. To study the impact of globalization and migration on remittances, we used the following regression panel model.

$$
x_{i, t}=\alpha+\beta_{1} y_{i, t}+\beta_{2} z_{i, t}+\delta_{i}+\gamma_{t}+\varepsilon_{i, t}
$$

Where i represent the country, the time period, $\varepsilon_{i, t}$ represents the residual variable, $\delta_{\mathrm{i}}$ represents the random or fixed effects for the cross section units, $\gamma_{\mathrm{t}}$ represents the random or fixed effects for periods of time.

We used the following notations:

$\mathrm{x}_{\mathrm{i}, \mathrm{t}}=\mathrm{LREM}$-logarithm of the number of remittances (expressed as a share of GDP) (endogenous variable)

$\mathrm{y}_{\mathrm{i}, \mathrm{t}}=\mathrm{LEMM}$ - logarithm of the number of emigrants (exogenous variable)

$\mathrm{z}_{\mathrm{i}, \mathrm{t}}=\mathrm{LKOFGI}$ - logarithm of Globalisation Index (\%) (exogenous variable)

To study the impact of remittances on economic growth we can analyze the relationship between GDP and remittances, using the relationship:

$$
\mathrm{x}_{\mathrm{i}, \mathrm{t}}=\alpha+\beta_{1} \mathrm{y}_{\mathrm{i}, \mathrm{t}}+\delta_{\mathrm{i}}+\gamma_{\mathrm{t}}+\varepsilon_{\mathrm{i}, \mathrm{t}}
$$

$\mathrm{x}_{\mathrm{i}, \mathrm{t}}=\mathrm{LGDP}$ - logarithm of Gross Domestic Product (euro/capita) (endogenous variable)

$y_{i, t}=$ LREM - logarithm of the number of remittances (expressed as a share of GDP) (exogenous variable)

The variables of interest were considered for 28 European countries (EU members), their values corresponding to 2007 - 2016 time period, being provided by EUROSTAT database and KOF Swiss Economic Institute. The model and associated data were analyzed using the econometric package Eviews 8.

The main objective of the regression analysis is to explain as much as possible the variance of the dependent variable through the explanatory variables used in the associated models. We chose these variables because they are used in most studies about the growth of the economy. In addition to these variables, we thought it would be interesting to include the variable globalization because we are in a time when globalization is constantly growing.

A regression on panel data is different from a single cross-sectional regression or a time series regression, in that the first one has a double index on its variables. There are the following types of panel data models : common-effect models (CEs), fixed-effect models (FEs) and random-effects models (REs).

\section{The econometric analysis}

In order to decide whether a RE, CE or FE model is more appropriate, different tests may be performed : Hausman Test and Chow Test.

\section{Remittances and globalization}

In the first part of this article we will check whether remittances are influenced by emigrants and globalization. 


\section{Hausman Test}

H0: Random effects (errors are not correlated with regressors)

H1: Fixed effects (errors correlated with regressors).

Table 1. Correlated Random Effects - Hausman Test

Correlated Random Effects - Hausman Test

Equation: EQ01

Test cross-section random effects

\begin{tabular}{lrrr}
\hline \hline Test Summary & Chi-Sq. Statistic & Chi-Sq. d.f. & Prob. \\
\hline \hline Cross-section random & 29.830482 & 2 & 0.0000 \\
\hline \hline
\end{tabular}

Source: Authors' own research.

The probability obtained from the Hausman-Test is less than 0.05 (Chi-Sq $=29.83$, Prob $<$ chi2 $=0.00$ ), which means that the alternative hypothesis is accepted that errors are correlated with the regressors, so the model used will be the one with fixed effects.

Chow Test

H0: Common effects (p.value > 0.05)

H1: Fixed effects (errors correlated with regressions) (p.value $<0.05$ )

Table 2. Redundant Fixed Effects Tests - Chow test

Redundant Fixed Effects Tests

Equation: EQ01

Test cross-section fixed effects

\begin{tabular}{lrrr}
\hline \hline Effects Test & Statistic & d.f. & Prob. \\
\hline \hline Cross-section F & 69.129999 & $(27,246)$ & 0.0000 \\
Cross-section Chi-square & 593.482949 & 27 & 0.0000 \\
\hline \hline
\end{tabular}

Source: Authors' own research.

From the above output, the null hypothesis is rejected, the difference between the two estimators is high, then the alternative hypothesis that we will choose the fixed-effect model is accepted. Taking into account the two tests we will use for our analysis the model with fixed effects.

Panel Regression

The hypotheses checked to see if the regression model parameters on panel data are significant and the model can be estimated are as follows:

H0: Parameters of the regression model are not significant

H1: Parameters of the regression model are significant

The equation parameters are significantly different from zero and the R-squared coefficient is 0.9879 , which shows that $98 \%$ of the remittance variation is influenced by the variables in the model, Globalization and the number of emigrants. Therefore, the factors used in the model are significant.

The Adjusted R-Squared Coefficient represents the value of the determinant coefficient (R Square) 98\%. The significance threshold for the $\mathrm{F}$ test is less than 0.05 , 
therefore the null hypothesis is rejected and the alternative hypothesis is accepted, there is at least a coefficient $\beta_{\mathrm{i}}$ significantly different from zero, it results that the regression model is valid, the results being guaranteed by probability of $95 \%$. It can be said that there is a significant relationship between the dependent variable and the independent variables.

The analyzed equation highlights the dependence of globalization remittances and the number of emigrants, the links between the factors being analyzed being positive. Coefficients were obtained through the fixed-effect model and have the following interpretations: a 1\% increase of the number of emigrants would increase remittances by $0.0038 \%$. The positive relationship between the two is explained by the increase in the number of emigrants that also favors the growth of the procentage of remittances from GDP that have a positive impact on the economy.

Regarding the effect of globalization, it is positive, the coefficient obtained by the model being 2.76 . Thus, the $1 \%$ increase in the globalization index means a $2.76 \%$ increase in remittances.

Table 3. Panel Regression

Dependent Variable: LREM

Method: Panel EGLS (Cross-section weights)

Date: 04/20/19 Time: 22:21

Sample: 20072016

Periods included: 10

Cross-sections included: 28

Total panel (unbalanced) observations: 276

Linear estimation after one-step weighting matrix

\begin{tabular}{crrrr}
\hline \hline Variable & Coefficient & Std. Error & t-Statistic & Prob. \\
\hline \hline C & -12.26344 & 2.964546 & -4.136702 & 0.0000 \\
LEMM & 0.003899 & 0.025157 & 0.154969 & 0.0570 \\
LKOFGI & 2.767425 & 0.689274 & 4.014983 & 0.0001 \\
\hline \hline
\end{tabular}

Cross-section fixed (dummy variables)

\begin{tabular}{llll}
\hline \hline & \multicolumn{2}{l}{ Weighted Statistics } & \\
\hline \hline R-squared & 0.987912 & Mean dependent var & 0.039027 \\
Adjusted R-squared & 0.986487 & S.D. dependent var & 2.293238 \\
S.E. of regression & 0.266564 & Sum squared resid & 17.47981 \\
F-statistic & 693.2704 & Durbin-Watson stat & 1.121570 \\
Prob(F-statistic) & 0.000000 & & \\
\hline \hline & Unweighted Statistics & \\
\hline \hline R-squared & 0.930152 & Mean dependent var & 0.016548 \\
Sum squared resid & 18.61399 & Durbin-Watson stat & 0.959063 \\
\hline \hline
\end{tabular}

Source: Authors' own research.

In other words, globalization has a rather large effect in increasing the number of remittances, because globalization and people are free to move from one country to another 
without restrictions.

\section{Remittances and GDP - economic growth}

The ability of remittances to reduce poverty and promote human development is well documented and has often been reported as being beneficial to countries' development.

Migration is often seen as a negative thing for the country of origin, but due to remittances, it also has a positive side because it helps to develop gaspowers and investments.

As a result of their growing volume and stable nature, remittances have becoming a subject of interest to many economists. According to the World Bank estimates, in 2015, developing countries received up to USD 441 billion, out of the total of 601 billion remittances, nearly three times the value of official development aid. The real value of remittances implies greater significance, taking into account unregistered flows through formal and informal transmission channels.

In this section of the article we will study the effects of remittances in economic development.

Hausman Test

H0: Random effects (errors are not correlated with regressors)

H1: Fixed effects (errors correlated with regressors)

Table 4. Correlated Random Effects - Hausman Test

Correlated Random Effects - Hausman Test

Equation: Remittances and GDP

Test cross-section random effects

\begin{tabular}{lrcr}
\hline \hline Test Summary & Chi-Sq. Statistic & Chi-Sq. d.f. & Prob. \\
\hline \hline Cross-section random & 29.620383 & 1 & 0.0000 \\
\hline \hline
\end{tabular}

Source: Authors' own research.

The probability obtained from the Hausman-Test is less than 0.05 (Chi-Sq $=29.62$, Prob $<$ chi $2=0.00$ ), which means that the alternative hypothesis is accepted and the model used will be the one with fixed effects.

Chow Test

H0: Common effects (p.value $>0.05$ )

H1: Fixed effects (errors correlated with regressions) (p.value $<0.05$ )

Table 5. Redundant Fixed Effects Tests - Chow test

Redundant Fixed Effects Tests

Equation: Remittances and GDP

Test cross-section fixed effects

\begin{tabular}{lrrr}
\hline \hline Effects Test & Statistic & d.f. & Prob. \\
\hline \hline Cross-section F & 686.784169 & $(27,251)$ & 0.0000 \\
Cross-section Chi-square & 1208.437774 & 27 & 0.0000 \\
\hline \hline
\end{tabular}

Source: Authors' own research. 
The null hypothesis is rejected, the difference between the two estimators is high, so the alternative hypothesis that we choose the fixed-effect model will be accepted.

Both the Hausman test and the Chow test have shown that the fixed-effect model is the most appropriate.

\section{Panel Regression}

When estimating the regression model on panel data, we logged the variables for standardization. Gross Domestic Product per capita is expressed in euro per capita, remittances are expressed as a share in gross domestic product.

Value of the F (1202.62), with a probability threshold Prob> F = 0,000 it results that the null hypothesis is rejected and the alternative is accepted according to which there is at least a fixed effect significantly different from zero, consequently the model can be estimated, the results being guaranteed with a probability of $99 \%$.

Since all the regression model parameters are significant, there is at least one fixed effect different from zero, 99.17\% (Adj R-squared) of the GDP variance is explained by remittances, the model has significant fixed effects.

\section{Table 6. Panel Regression}

Dependent Variable: LGDP

Method: Panel Least Squares

Date: 04/20/19 Time: 22:24

Sample: 20072016

Periods included: 10

Cross-sections included: 28

Total panel (balanced) observations: 280

White cross-section standard errors \& covariance (d.f. corrected)

\begin{tabular}{|c|c|c|c|c|}
\hline Variable & Coefficient & Std. Error & t-Statistic & Prob. \\
\hline $\mathrm{C}$ & 12.16185 & 0.034945 & 348.0235 & 0.0000 \\
\hline LREM & 0.109539 & 0.019387 & 5.650189 & 0.0000 \\
\hline \multicolumn{5}{|c|}{ Effects Specification } \\
\hline \multicolumn{5}{|c|}{ Cross-section fixed (dummy variables) } \\
\hline R-squared & 0.992601 & \multicolumn{2}{|c|}{ Mean dependent var } & 12.16535 \\
\hline Adjusted R-squared & 0.991776 & \multicolumn{2}{|c|}{ S.D. dependent var } & 1.544687 \\
\hline S.E. of regression & 0.140083 & \multicolumn{2}{|c|}{ Akaike info criterion } & -0.995354 \\
\hline Sum squared resid & 4.925450 & \multicolumn{2}{|c|}{ Schwarz criterion } & -0.618894 \\
\hline Log likelihood & 168.3496 & \multirow{2}{*}{\multicolumn{2}{|c|}{$\begin{array}{l}\text { Hannan-Quinn criter. } \\
\text { Durbin-Watson stat }\end{array}$}} & -0.844355 \\
\hline F-statistic & 1202.624 & & & 1.030791 \\
\hline Prob(F-statistic) & 0.000000 & & & \\
\hline
\end{tabular}

Source: Authors' own research.

Remittances have a positive effect on Gross Domestic Product per capita. An increase in money sent to cross-border workers (as a percentage of GDP) in the country of origin by $1 \%$ leads to an increase in GDP of $0.10 \%$.

So remittances have an important role in boosting the economy. 


\section{Conclusion}

Remittances are an important source of foreign transfers to developing countries and are considered as a financial development mechanism.

Following the above tests, we have come to the conclusion that remittances help the economy of a country. Remittances also grew during this period of growing globalization, so they are heavily influenced by the age we are in. If remittances are used appropriately, investment, health education, many of the developing countries will be helped.

Given that they represent an important source of income for migrant families, they and migrants have an important role to play in the economy of their country of origin as well as in the destination country. Poverty provides relevant information about a country's population, its economic status, ways in which its members seek to overcome the poverty line and ensure a decent living standard.

Therefore, estimating a statistical and econometric model that studies the correlation between the effect of remittances, and the economic level can lead to the development of government policies in which remittances are given a more prominent status, given their benefits in reducing poverty.

\section{References}

Aggarwal, R., Demirguc-Kunt, A. and Peria, M.S.M. (2011). Do remitances promote fi nancial development?. Journal of Develoment Economics, 96, 255-264

Anghelache, C., Niță, G. and Badiu, A. (2016). Migrants remittances - an important and stable source of external funds, in the economic development of a country. Romanian Statistical Review Supplement, 12, 83-90

Chirtoc, I.E.; Bălăcescu, A. (2010) Efectele pozitive ale fenomenului mobilității forței de muncă asupra contului curent al României, Analele Universităţii "Constantin Brâncuşi” din Târgu Jiu, Seria Economie , Nr . 4: 154-164

Conway, D., Potter, R., St.Bernard, G. (2012). Diaspora Return of Transnational Migrants to Trinidad and Tobago: The Additional Contributions of Social Remittances. International Development Planning Reivew 34(2), 189-209.

Giuliano, P. and Ruiz-Arranz, M., (2009). Remittances, Financial Development and Growth. Journal of Development Economics, 90, 144-152

https://www.kof.ethz.ch/en/forecasts-and-indicators/indicators/kof-globalisationindex.html

Ledesma, L.; Piracha, M. (2004), International Migration and the Role of Remittances in Eastern Europe, International Migration, 42(4): 65-84.

Roman, M.; Ileanu, B. (2010) Modelarea deciziei de remitere a emigranților est-europeni, Studii si Cercetari de Calcul Economic si Cibernetica Economica, Vol. 44, Nr. 3-4: 87-97

Ledesma, L.; Piracha, M. (2004), International Migration and the Role of Remittances in Eastern Europe, International Migration, 42(4): 65-84. 